\title{
RESEARCH METHODOLOGY FUNDAMENTALS OF THE UKRAINIAN PROCESSING AND MANUFACTURING ENTERPRISES ECONOMIC POTENTIAL
}

\author{
Yurii GUDZ1', Tetyana ZADNIPRANNA ${ }^{2}$, \\ Donetsk National University of Economics and Trade named after Mykhaylo Tugan-Baranovsky, Ukraine
}

\begin{abstract}
The purpose of the paper is to find the most appropriate application ways for simulating of the business activities of the manufacturing and processing agriculture enterprises dealing in the corruptive Ukrainian environment and to overcome the fundamental methodology contradictions to be able to perform more accurate results of the economic potential assessment despite the sophisticated defects inherent in current industry sector. Methodology includes publication research, interviews and practical comparison of the published statistic data and real production volume, returns and other indicators to be able to estimate actual potential of the target enterprises. The paper comes through the classical analytical methods showing their application pros and contras in highly corruptive environment with the strong trend of data falsification. Results of the survey show the basic economic methods applicable for the research activity of processing and manufacturing enterprises operating in the field of agriculture. The authors' experience picks up the problem of the urgent need of new methodology among vast abstractive researching executed by the majority of the scientists as they have some contradictions when we apply them for the real industry segment or even an enterprise. Corruption affecting the general statistic data misrepresents the facts therefore current (classic methods) are not able to show real economic trends in the industrial segment. So the authors persist on the significance of the corruption distortion considering e.g. to identify the actual macro- and microeconomic indicators, indexes and ratios we involve the stage researching system of multidimensional comparative analysis to rank received rating and find appropriate position for enterprise and as we cannot ignore a constantly growing shadow sector of Ukrainian economy we perform economic potential assessment of the target enterprise with the identification of the shadow sector with the help of the offered in the paper formula. This set of the mentioned above tools allows us to estimate the influence of the inner and outer environment influence into the researchable object and show the actual phenomena trends. Another benefits of the offered ranking system is involving of several scientific approaches (every approach obtains its own pros and contras) so if they deal together we increase our accuracy. Practical implications. Ukraine has been being independent over a quarter of a century and unfortunately corruption has penetrated into each and every sphere of social and economic life including agriculture and due to the a great deal of fabricated data leading domestic scientist to study the macro- microeconomic state and processes mostly from the abstractive point of view. Therefore the methodology clarification and algorithm of the analytical method application estimate the target enterprises' economic potential more accurate. Value/originality. Considering the identification of the shadow industry sector (the volume Ukrainian scientists cannot ignore) we may avoid dramatic mistakes in researches defining macroeconomic indexes, other economic and financial options.
\end{abstract}

Key words: economic research methodology, general purpose research methods, specific research methods, multidimensional comparative analysis, identification of shadow sector, assessment of the economic potential.

JEL Classification: C10, G10, G17, N55

\footnotetext{
Corresponding author:

${ }^{1}$ Department of Finance and Banking, Donetsk National University of Economics and Trade named after Mykhayilo Tugan-Baranovsky. E-mail:hudz@inbox.ru

${ }^{2}$ Department of Accounting and Audit, Donetsk National University of Economics and Trade named after Mykhayilo Tugan-Baranovsky. E-mail:0676120330@mail.ru
} 


\section{Introduction}

For 25 years of Independence, Ukraine has been turned into the most corruptive country in Europe. Corruption has penetrated into the each and every sphere of social life including economical researches. Invalid data of the enterprises, its manipulation for purposes of general statistics, double economic or political standards, conflicting legislation actually make impossible true research results. Virtually all the set of laws in the country that have been launched by the authorized bodies is adapted to suit the needs of both oligarchic groups and deputies themselves running their business by means of fictitious persons.

There is hardly ever a research methodology (almost any modern system) involving true data. To gain information concern the particular state we need to conduct a complex research. The core issue in the methodology of the economic activities is to implement the methods showing the real nature of the process. Unfortunately the majority of the Ukrainian scientists study the macro-microeconomic states and processes from the abstractive point of view.

For the processing and manufacturing enterprises it is worse to apply general purpose economical methods and the micro- macroeconomic ones to study the activity of the enterprise and the set of special and general purpose ones to study not only the enterprise's activities but the whole industry. Therefore it is rather sophisticated to study the economic research methods.

The issue is the sphere of interests for a wide range of domestic and overseas scientists: M. Andreev (Guidelines, 2004), K.P. Vlasov (Research Methods and Arrange of Experiments, 2002) I.F. Zinov'ev (Methods of economic research, 2005), A.B. Ignatieva , E.M. Korotkov (Research of management, 2003), B.l. Krutov, F.A. Kuzin (Master's Thesis, 1997); M.M.Maksimtsev (Reserch of Management Systems, 2005), C.B. Mocherniy (Methodology of Econoic Research, 2001), Vladimir Popov (The Basis of Scientific Research, 1989), S.Ya. Saliga (Fundamentals of assessment of economic effectiveness of companies, 2007 \& Methods improvements in company's economic activity assessment, 2007), V.M. Sirih (The method of jurisprudence: the basic elements of the structure, 1989), S.A. Smirnov, V.A. Tihomirov (Guidelines to write thesis and abstracts, 2004), S.G. Cheremisina (Methods of economical researches, 2005).

The thesis purpose is to show the basic economic methods applicable for Ukrainian agriculture processing and manufacturing economical researches.

\section{Basic methodology elements and the research methods}

The form of any science existence including management and economics is a scientific research. Scientific research is the activity designed for complete study of an object, a process, a state, a structure or communication then to define and apply useful results. The basis for the scientific research is its methodology (Information: Acquisition, Protection, Analysis Textbook on Information and Analytical Work, 2001).

To the point of S.V. Mochrnonyi's view, methodology is the set of the different methods and tools for scientific cognizing (Methodology of economic research, 2001). E.M. Korotkov concerns research methodology as a set of purposes, approaches, guidelines, priorities, means and methods of the research conducting (Research of management systems, 2003). The dictionary written by S.I. Ozhegov and N.Iu. Shedova defines the term with two meanings: a set of methods applicable for different fields of activities; and as the doctrine on new methods to get knowledge (Ozhegov, Shvedova, 1999). A new methodology definition is demanded as the mentioned above ones include some defects: the methodology is not only a set of methods but it is a particular algorithm how to conduct them as well as defined purposes and tasks; therefore the research methodology is a complex system to cognize particular phenomena, including particular goals, tasks, algorithm and methods of economical researches.

The basic methodology elements are the research methods.

Such scientists as P.I. Andreev, S.A. Smirnov, V.A. Tykhomyrov admit that the research method is as system of orders, guidelines, samples showing how to do something (Andreev, 2004). Scientists V.I. Krutov and V.V. Popov have another point of view. They maintain opinion that the methodology is the way to cognize objective reality. Ukrainian scientist K.P. Vlasov concern the method as either the set of tools and operations of practical research conduction or theoretical cognizing of the reality in order to solve special problems (Vlasov, 2002).

Organizing the scientists' statements we can define the method of economic researches. The method of economic researches is a set of research stages of phenomena, process or objects involved to define key features. To study the particular phenomena we ought to use not a single research method but the set of ones. V.M. Syrykh deals with general purpose, philosophic or other special methods (Syrih, 1980).

In F.A. Kuzin's view the research methods can be shared into two groups: the ones of general purposes and the special ones. He shares the general purpose ones into three large subgroups: empirical research methods (watching, comparison, measurement, experiment); the mixed methods implemented for the levels of empirical and fundamental researches (abstracting, analysis, synthesis, induction, deduction, simulating); method of fundamental research (the adaptation from abstraction to concrete one), (Kuzin, 1997).

K.P. Vlasov and S.V. Mocherny present the similar classification of the scientific research methods. They consider there are general purpose ones, disciplinary ones and interdisciplinary ones (Mocherny, 2001). The Russian scientists G.I. Andreev and S.A. Smyrnov and 
V.A. Tykhomyrov just give the list of the general purpose methods e.g. watching, comparison, measurement, experiment, abstracting, analysis and synthesis, induction, deduction, simulating, idealization, formalization, logical methods and historical one (Andreev, 2004).

A.V. Ignatiev and M.M. Maksymntsev say completely different ideas about the methods in their book (Ignatiev, 2000). They admit there are the basic types:

1) based on the specialists' experience and intuition;

2) system of formalizing presentation;

3) complex ones.

I.F. ZinovieV, S.Ia. Salyga, F.V. Zinovieva and S.G. Chremisinoi (Zinov'ev, 2005, page 8) study major local methods e.g. formalizing of economic circumstance, designing methods, analysis of indexes, convention analysis, grouping method, a method of the relative values, economic and mathematical simulating, method of analogues, method of forecasting based on the indicating values, marketing methods, the methods of the assessment of the shadow economy, methods of the economic risk assessment, a methods of couple comparison based on the multivariate scales.

To study the effectiveness of the economic potential management we need to form the general set of the research methods based on the domestic and overseas scientists' experience.

\section{The basic general purpose methods for effectiveness assessment}

The basic general purpose methods suitable for effectiveness assessment of the economic potential application between processing and manufacturing enterprises are watching, comparison, abstracting, analysis and synthesis.

The methods of measurement and experiment are not applicable to study economical phenomena. The experiment and measure methods suits more perfectly for technical and agriculture sciences. To study the economic potential of the processing and manufacturing enterprises

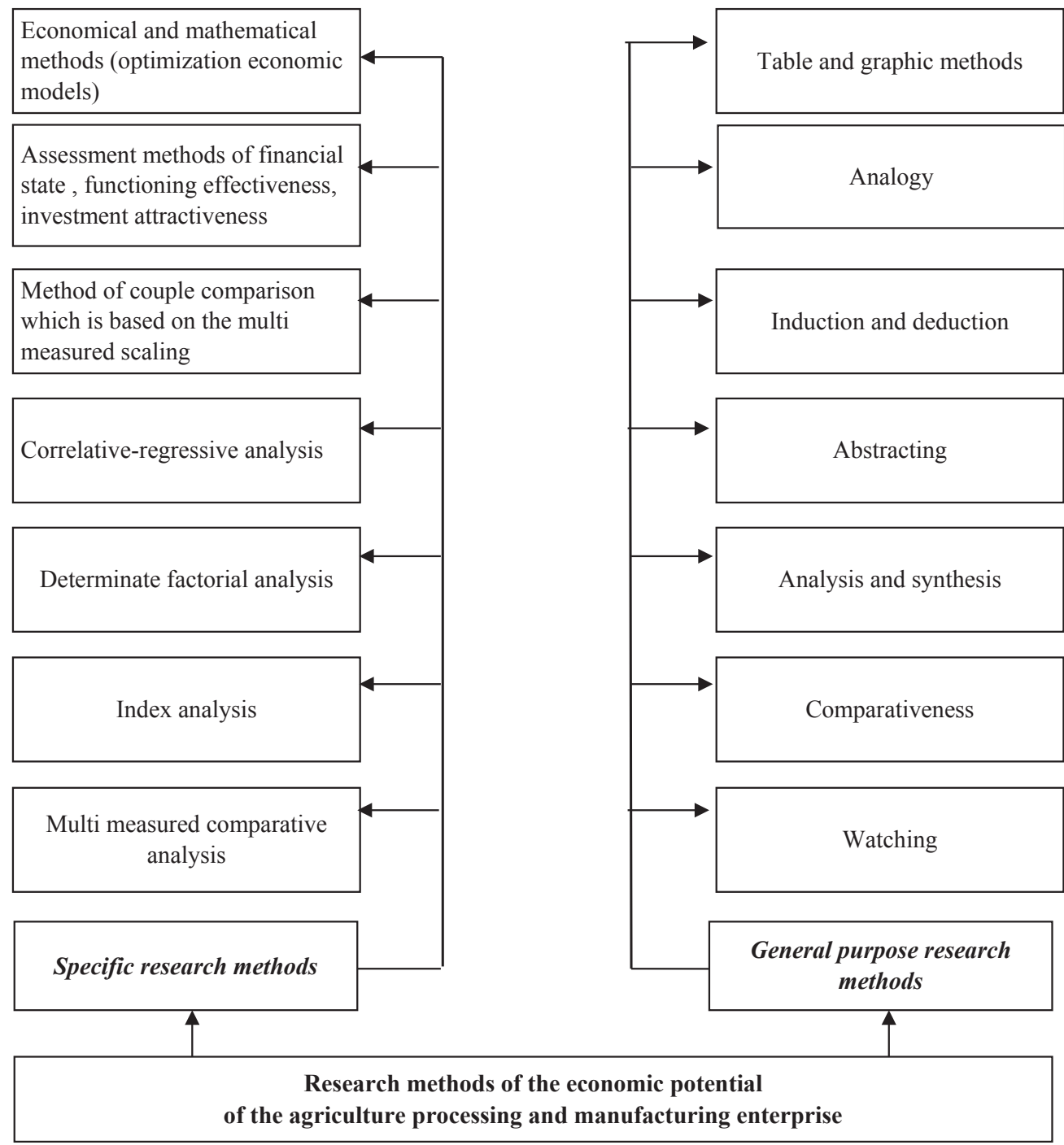

Pic. 1. Research methods of the economic potential of the agriculture processing and manufacturing enterprise 
Chart 1

Stages of the multidimensional comparative analysis

\begin{tabular}{|c|l|}
\hline Stages & \multicolumn{1}{|c|}{ Description } \\
\hline 1 & $\begin{array}{l}\text { Definition of the indexes which serve as ground for the } \\
\text { economic activity assessment, the information about } \\
\text { the indexes is collected and applied for the outlet data } \\
\text { matrix }\end{array}$ \\
\hline 2 & $\begin{array}{l}\text { We define an optimal element in the every column and } \\
\text { make it equal to one. Then all the elements of the } a i j \\
\text { column are divided into the optional element of the } \\
\text { standard enterprise }(\text { max aij). As a result we get a matrix } \\
\text { of standardized ratios }(x i j) . x i j=a i j / m a x ~ a i j\end{array}$ \\
\hline 3 & $\begin{array}{l}\text { All elements of the coordination matrix are squared. If } \\
\text { the target considers different weights of the ratios so the } \\
\text { squared means have to be multiplied by the means of } \\
\text { the corresponding weighted indexes }(K) \text {. calculated in } \\
\text { compliance with: } R j=K 1^{*} x j 2+K 2^{*} x 2 j 2+\ldots K n^{*} x n j 2\end{array}$ \\
\hline 4 & $\begin{array}{l}\text { The rank the received ratings }(R j) \text { and find the position } \\
\text { for every enterprise }\end{array}$ \\
\hline
\end{tabular}

in the field of agriculture we can apply induction, deduction and analogies.

Watching shall be defined as the regular, systematic and dedicated perception of the whole or partial process and other objects. The watcher does not interrupt the object's behaviour in favour of tactics to catch the one's features and characteristics. The methods show what the objects have in common or in particular in the further process of the compassion.

Analysis and synthesis are the complex methods based on the consequent implementation of the set of tools and trends when sharing the target objects on the basic parts, elements and features (analysis) and combination of the particular objects into the one whole (synthesis). Analogy is the method of scientific cognizing applicable for getting knowledge form the similar objects. Induction and deduction form the set of the researches which depends on each other, it is planning process from the particles to the whole, from less common statements to a bit more common (induction) and vice versa (deduction).

Abstracting is the imaginative deviation away from the basic features, correlation and affairs and the simultaneous sharing of just one of a few features of the object. We also can speak about such research methods as graphic one or table one. Infographic helps to see the general trends of the economic phenomena and the information arranged as a chart suits better for calculating and applicable for systematization and comparison.

The specific methods can be used for economic potential management analysis and the forms of the methods are listed below:

- Multidimensional-comparative analysis; index analysis;

- Means of determinate factor analysis which include:

- Chain substitution, absolute differences, a method of relative differences, integral method;

- Correlated-regressive analysis;

- A method of couple comparison based on the multidimensional scaling;
- assessment methods of the financial state, effective functioning and investment effectiveness;

- Economical and mathematical methods (optimization economic simulating).

Graphic methods of economic potential management at the agriculture processing and manufacturing enterprises are shown in the picture shown in Picture 1.

Let's study the stages of the research conducting and specific features of every mentioned above method. Multidimensional comparative analysis is necessary for the complex assessment of the enterprises' economic activity results. We meet such a task if we face a need to make ratings of a few enterprises (Savitskaya, 2002). The basic stages of the multidimensional comparative analysis are placed in the chart (Chart 1).

With the help of the couple comparison method based on the multidimensional scaling we can find influence of the inner and outer environment into the system state. The method is applicable for every segment of agriculture industry and for the enterprise at the micro level.

The first stage of the methods is to create the hierarchy of demands to the structure. Such hierarchy allows finding the most significant elements showing the essence of the problem at the assessment stage and find correlation between them. The second stage is the conduction of the couple comparativeness in the matrixes founded at the every stage of the hierarchy. The third stage is the definition of the influence and ranking of the limit (Zinov'ev, 2005 \& 1999).

The method of the correlative-regressive analysis belongs to statistic methods. The basic tasks of the method are to analyse statistical data and find the mathematical correlation among the researchable features and define with the help of the correlation index correlative intensity. Afterwards we have defined the correlation between the phenomena and quality of the correlation we implement statistics (correlative and regression methods) to form a numeral correlation. Correlative and regression methods fulfil two basic tasks:

- they define with the help of regressive equation the analytical form of correlation between $x$ and $y$ characteristic variations;

- they define the level of the intensity among the characteristics.

\section{Practical implication}

In economic and statistic researches we often use straight-line form of correlation, described by the following regressive equation $y x=a O+a 1 x$, double factor simulating model is defined by the equation $y x=a 0+a 1 x 1+a 2 \times 2$ (Vashkiv, Pasteur, Storozhuk, 2001).

Economic indexes are relative means characterizing the trends in economic phenomena concern time, space or concern any other factor. Economic researches are often used the index of general commodity value. The index is made as a ratio of sales volume (in money units) and 
forms on the base if price and the product amount. At the decomposition of the general index we can define a general influence of every of them (Zinov'ev, 2005; Marmoza, 2005; Zinoviev, 1999; Vashkiv 2001).

Relative and absolute change of the monetary volume of the sold products in the base period to compare with the reported one are calculated on the base of two factors: real volume of the products and the prices. Therefore we shall define the index of monetary volume of the production:

$$
\operatorname{Ig} p=\frac{\sum g 1 p 1}{\sum g 0 p 0} .
$$

The difference between numerator and denominator shows the absolute increase of the sold product increase and as a result the changes in the real production volume makes:

$$
\Delta g p=\sum g 1 p 1-\sum g 0 p 0
$$

With the same objective we can calculate the index of the real physical volume of production:

$$
\operatorname{Ig} p=\frac{\sum g 1 p 0}{\sum g 0 p 0} .
$$

The absolute growth of the monetary volume of the sold products due to the real increase of the product volume and sales price changes makes:

$$
\Delta g p=\sum g 1 p 0-\sum g 0 p 0 .
$$

$$
\operatorname{Igp}=\frac{\sum g 1 p 1}{\sum g 0 p 0} \text {. }
$$

The absolute growth of the monetary volume of the sold basic production due to the price change makes:

$$
\Delta g p=\sum g 1 p 1-\sum g 1 p 0 .
$$

Define the indexes and the absolute growth with following mutual correlation:

$$
\begin{aligned}
& I g p=I g \times I p . \\
& \Delta g p=\Delta g+\Delta p .
\end{aligned}
$$

As factorial analysis we understand the methodology of the complex and systematic study and measurement of the factor influence onto the means of the resultative indicators (Zinoviev, 1999 \& 2005; Savitskaya 2002). The basic task of the factor analysis is the following:

- selection of the factors for analysis of the research of resultative indicators;

- classifying and systematization of the factors in order to provide complex and systematic approach to study the factor influence into the economic activity;

- to study the forms of the dependence and simulating between factor and resultative characteristics;

- calculation of the factor influence and the every factor role assessment at the changing environment;

- operation with factorial model.

The factor analysis obtains three types of the popular models:

- Additive ones:

$$
Y=\sum_{i=1}^{n} X i=X 1+X 2+X 3+\cdots+X n
$$

$$
\begin{aligned}
& \text { Multiplicative ones: } \\
& Y=\prod_{i=1}^{n} X i=X 1+X 2+X 3+\cdots+X n
\end{aligned}
$$

- Multiple ones:

$$
Y=\frac{X 1}{X 2}
$$

- Mixed ones:

$$
Y=\frac{a+b}{c} ; Y=\frac{a \times b}{c} \text {. }
$$

Estimating the financial state we usually apply the ratios of the property, economic activity volume, purchasing capacity, cash position; investment attractiveness. The corrective indexes are applied to get accurate financial means.

To estimate the financial state and investment attractiveness we implement such basic indicators: depreciation ratio, renovation ratio, dropout ratio, ratio of the active share of the fixed assets, indicator of the operative capital of the enterprise, operative capital flexibility, funding ratio, financial stability ratio, liquidity ratio (immediate, general, short-term), investment profitability ratio, equity capital ratio, sales profitability, manufacturing profitability, working account receivable ratio, floating finished product ratio, a ratio of the floating accounting payable etc. (Zinoviev, 1999 \& 2005; Savitskaya 2002).

The scientific literature defines effectiveness of economic activity with the set of different ratios, but they don't reflect the general state of the effectiveness of the processing and manufacturing activity.

General indicator of the effectiveness of the processing and manufacturing activity is described by L.I. Kyrylova, S.Ia. Salyga, K.S. Salyga, O.V. Skackova (2007).

General indicator of the effectiveness of the processing and manufacturing activity is calculating with a formula:

$$
E=\frac{T}{C o+C_{M}+K u+Y} .
$$

Where is an indicator of the economic activity of the company;

This is volume of the commodities, produce at one circle of the monetary capital, UAH;

Co - average annual costs of the fixed assets and material property;

$\mathrm{CM}$ - capitalized material and other costs, $\mathrm{UAH}$;

$\mathrm{Ku}_{\mathrm{u}}$ - ratio of the turning the labour costs into the monetary costs;

$\mathrm{Y}$ - number of working people.

Research literature contains long and routine calculations and it contains a floating ratio to show capitalization of the remuneration, profit, material costs that doesn't suit general average annual effectiveness of the process and manufacturing of economic activity.

The better result shall be got with the next formula:

$$
E=\frac{\text { ЧРР }}{\text { Сo }+ \text { См }+ \text { ЗПріч } x Ч} \text {. }
$$

where ЧАP - net operating income; 
$\mathrm{Co}$ - value of the fixed assets;

$\mathrm{C}_{\mathrm{M}}$ - material costs (the value of the floating funds);

ЗПріч - annual remuneration pro one worker;

$\mathrm{Y}$ - number of the working people.

So we can summarize that the formula shows the effectiveness of the involved resources for to fabricating the products. Linear programming is an issue of the optimal (mathematical) programming responsible for tasks arranging. The economy meets such tasks at the practical implementation of the optimal principles of management and planning (Fedoev, 2000). To realize the optimal principles of management and planning means to solve the following task:

$$
\max (\min ) f \overline{(X)} \bar{X} \varepsilon D,
$$

where - is a mathematical note of the optimal criteria for the target function.

The task for optimization we can write the following way:

To find the minimal or maximal meaning:

$f \overline{(X)}=f(x 1, x 2, \ldots x n)$.

With limitations:

$\varnothing 1(\mathrm{x} 1, \mathrm{x} 2, \ldots \mathrm{xn})\{\leq, \geq,=\} \mathrm{b} 1$,

$\varnothing_{2}(\mathrm{x} 1, \mathrm{x} 2, \ldots \mathrm{xn})\{\leq, \geq,=\} \mathrm{b} 2$,

$\varnothing 3(\mathrm{x} 1, \mathrm{x} 2, \ldots \mathrm{xn})\{\leq, \geq,=\} \mathrm{bm}$,

$x j \geq 0, j=$

Making a research we accept the information as one of the basic part there. To study economical potential of the enterprise we can use statistical statements of the company, internet-resources, annual statistical data base issued for the needs of the researchable region.

Statistic statements are presented in different papers. The basic forms of the statistical statements used in researches to study economical potential of the processing and manufacturing enterprises in Ukraine are: a report for manufacturing of business commodities (paper №1-П), labour report (paper №1-ПВ), report on used operational time (paper - ЗПВ), report on number of the working people, their qualification and training (paper № 6-ПВ), report on availability and move fixed assets, amortization (depreciation) (paper № 11-03), balance sheet (paper
№ 1), financial report (paper №2), flow of funds report (paper № 3), report on equity capital of the company (paper № 4).

The shadow economic segment is growing in Ukraine. The volume of the shadow economic activity reached the volume you cannot ignore otherwise you will receive wrong dramatic mistakes in your research defining macroeconomic indexes, economic and financial options. Making the economic potential assessment of the processing and manufacturing enterprises we shall consider the identification of the shadow sector of the Ukrainian economy. To find the volume produced by the shadow industry sector we can apply the following formula:

$$
\mathrm{Vt}=\frac{\text { Імз }}{\mathrm{Iфp} \times 1,1} \times \mathrm{V} л \text {. }
$$

Where in $\mathrm{Vt}$ - the volume of the shadow production;

IM3- index of the material cost growth;

1,1 - corrective ratio set by the experts;

I $\phi \mathrm{p}$ - index of the real volume of the products;

$\mathrm{V}_{\Lambda}$ - volume of the official production.

\section{Conclusions}

The ground for any science is a scientific research. The core part of the scientific research is its methodology applied with a defined set of methods. By the way it is possible to conduct a research of the effective management of the economic potential with general purpose and specific methods. General purpose methods are watching, comparison, analysis, abstracting, synthesis, induction, deduction, analogy, charts and graphic methods.

Specific methods which are popular making an analysis of economic potential management are multidimensional comparison analysis, index analysis, means of determinative factor analysis (chain substitution, absolute differences, integral method, correlative-regressive analysis, method of couple comparison based on the multidimensional scaling, methods of the financial state assessment, functioning effectiveness, invest attractiveness, economical and mathematical methods (optimization of economical and mathematical models).

\section{References}

Andreev, M. (2004). Guidelines to write thesis and abstracts: the basis of scientific terms and presentation of research activities results: From Finance and statistics - Kyiv, 272 p.

Zinov'ev, I. (2005). Methods of economical researches: From Tavriya - Simferopol, 176 p.

Ignatiev, A.V. (2000). Research of management systems: From YUNITI - Kyiv, 157 p.

Korotkov, M.Z. (2003). Research of management systems: From INFRA - Moscow, 176 p.

Kuzin, F.A. (1997). Master's Thesis: From INFRA - Moscow, 304 p.

Kuznetsov, I.N.(2001). Information: acquisition, protection, analysis textbook on information and analytical work: From Publishing House Ltd. - Yauza - Moscow, 92 p.

Marmoza, A.T. (2005) Workbook for statistics: From Condor - Moscow, 512 p.

Zinoviev, F.V. (1999). Methods of economic research: studies: From Tavria - Simferopol, 168 p.

Vlasov, K.P. (2002). The method of research and the organization of experiments: From Kheson, $256 \mathrm{p}$.

Mocherny, S.V. (2001) Methodology of economic research: From Swit - Lviv, 416 p. 
Krutov, V.I., Grushko, I.M., Popov V.V., (1989). The basis of scientific research studies for technical Universities: From Vyushaya Shcola, 306 p.

Ozhegov S.I., Shvedova N.Y. (1999). Explanatory Dictionary of the Russian language: From ASB - Moscow, 944 p. Sabitov, R. (2002). Based on research: From - Chelyabinsk, 138 p.

Savitskaya, G.V. (2002). Analysis of the economic activity of the enterprise: Textbook: From New knowledge, 704 p. Syrih, V.M. (1980). The method of jurisprudence: the basic elements of the structure: From Legal Literature Moscow, $179 \mathrm{p}$.

Saliga, S.J., Saliga, K.S. (2007). Fundamentals of assessment of economic effectiveness of companies: From GU "ZIDMU" - Zaporizhzhya, 256 p.

Vashkiv, P.G., Pasteur, P.I., Storozhuk, V.P. (2001). Fundamental statistics: Students book: From Lybid, 320 p.

Saliga, S.J., Saliga, K.S. (2007). Methods improvements in company's economic activity assessment: From GU "ZIDMU" - Zaporizhzhya, 56 p.

Fedoev, V.V., Garmash, A.N., Dayitbegov D.M., (2000). Economic, mathematics and empiric methods and models: From UNITY - Moscow, $391 \mathrm{p}$.

\section{Юрий ГУДЗЬ, Татьяна ЗАДНИПРЯННАЯ}

ОСНОВЫ МЕТОДОЛОГИИ ИССЛЕДОВАНИЙ ЭКОНОМИЧЕСКОГО ПОТЕНЦИАЛА ПЕРЕРАБАТЫВАЮЩИХ ПРЕДПРИЯТИЙ В УКРАИНЕ

Аннотация. Целью работы является нахождение способов моделирования деятельности перерабатывающих предприятий в сельскохозяйственном секторе в условиях присущей Украине высокой коррупции и преодоления противоречий классической методологии для того, чтобы предоставить более точные результаты оценки экономического потенциала не смотря на значительные погрешности данных в этом секторе промышленности. Методика основывается как на опубликованных данных исследований и предоставленных интервью, так и на практическом сравнении официальных статистически данных, реальных объемов производства, доходов и других показателей, на основе которых оценивают экономический потенциал предприятий целевой выборки. Статья рассматривает классические аналитические методы, а также их сильные и слабые стороны с точки зрения практического применения с учетом погрешности объекта исследования находящегося в высоко коррумпированной среде с ярко выраженной тенденцией фальсификации данных для анализа. Результаты исследования показывают основные методы экономики, применимые для исследовательской деятельности сферы перерабатывающих предприятий работающих в сельском хозяйстве. Опыт авторов раскрывает проблему необходимости ввода новой методики, которая будет выгодно отличаться своей практической применимостью и позволит большинству ученых отойти от абстрагированности исследований. Так как из-за коррупции большая часть статистической информации имеет ряд значительных допусков, она не является достаточным основанием для выявления действительных экономических тенденций в промышленности. Авторы настаивают на более точном математическом определении влияния коррупции на макро- и микроэкономические показатели, используемые в поэтапных исследованиях - например, таких как многомерный сравнительный анализ для ранжирования предприятий в соответствии с заданными показателями. Мы действительно не можем игнорировать постоянно растущий теневой сектор украинской экономики при осуществлении оценки экономического потенциала предприятия, поэтому в процесс анализа вводим его математическую оценку. Набор вышеупомянутых приемов и инструментов позволяет нам оценить влияние внешних и внутренних факторов на исследуемый объект и действительные тенденции данного экономического явления. Дополнительными преимуществами предложенной системы ранжирования - это включение в процесс анализа нескольких подходов (с описанными их сильными и слабыми сторонами), которое в целом повышают точность полученных результатов. Практическое применение. Украина уже является независимым государством более 25 лет и, к сожалению, за это время коррупция проникла во все сферы социальной и экономической жизни страны, включая сельское хозяйство и, благодаря, большому количеству фальсификаций данных большинство отечественных ученных изучают макро- и микросостояния и процессы в основном с абстрактной точки зрения. Поэтому модернизация существующей методики и предоставление алгоритмов применяемых методов оценивают экономический потенциал целевых предприятий более точно. Значение оригинальность. Беря во внимание теневой сектор промышленности (уже в том объеме, который невозможно не игнорировать) мы можем избежать значительного искажения данных в исследованиях при вовлечении макроэкономических коэффициентов и других экономических и финансовых опций. 